Bull. Geol. Soc. Finland 42, 151-164 (1970)

\title{
THE DATA PROCESSING AND THE INTERPRETATION OF THE RESULTS IN PEDOGEOCHEMICAL EXPLORATION
}

\author{
Matti Kataja, ${ }^{1}$ Aimo Nurmi, ${ }^{2}$ Heikki Wennervirta ${ }^{3}$ and Erki Vornanen ${ }^{4}$ \\ ${ }^{1}$ State Computer Centre, Helsinki, Finland \\ ${ }^{2}$ Geological Survey of Finland, Otaniemi, Finland \\ ${ }^{3}$ Exploration Department, Outokumpu Company, Outokumpu, Finland \\ ${ }^{4}$ Rautaruukki Company, Otanmäki, Finland
}

\begin{abstract}
In this paper a report is given of the pedogeochemical study of the Makola area. Its subject matter is the automated prosessing of the data obtained from the pedogeochemical exploration as well as the factors affecting the results. Of these factors, special emphasis is laid on the statistical behaviour of the element concentrations in the sample population. A smoothing method was evolved to reduce the random component of the dispersion. For the automated print-out of the results programs were developed which permit the output of the data by a line printer or a computer-operated plotter.
\end{abstract}

\section{CONTENTS}

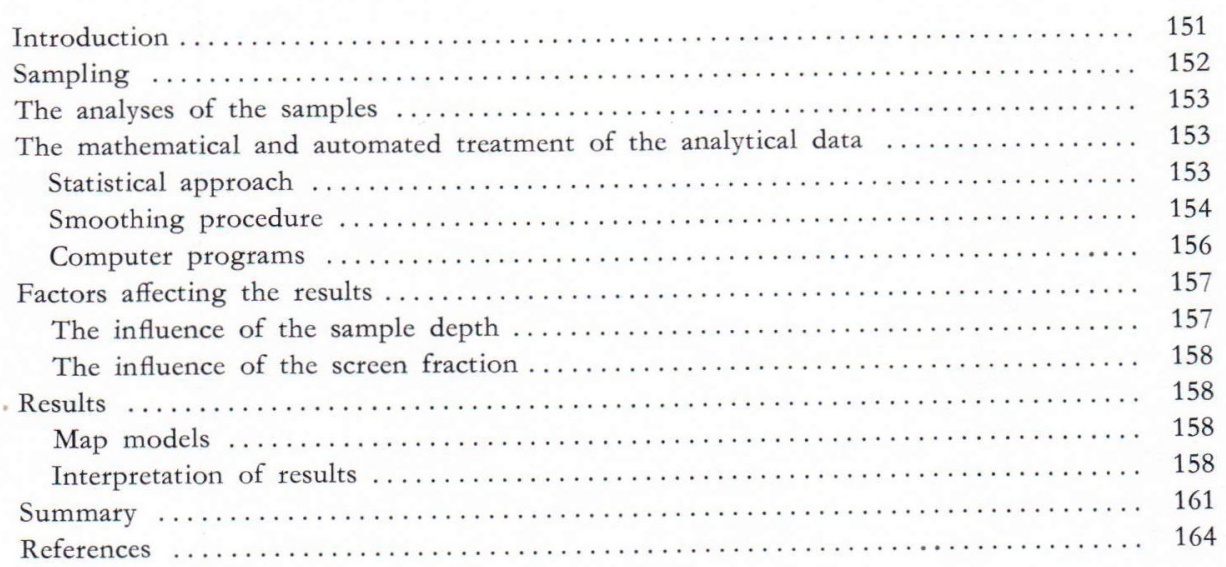

\section{Introduction}

The method of applied geochemistry which has received most attention in Finland is that of pedogeochemical exploration (Kauranne 1951,
1958, 1959, Tavela 1957 and Hyvärinen 1958). Even inspite of some negative experiences the method continues to be employed generally and attempts are underway to develop it still further. In 1965 the research commission of the Society of 
Mining Engineers (Vuorimiesyhditys - Bergsmannaföreningen ry) formed a committee to work on the methods used in the treatment of geochemical samples and in the interpretation of the results. The report was completed in 1967. It focuses most attention on the statistical treatment of pedogeochemical data and the possibilities of automated output of data. In order to acquire systematic observational material for the treatment of the results, the committee carried out a pedogeochemical model investigation in the Makola area. This area was chosen because previous geochemical investigations (Rankama, 1940, Kauranne, 1959 and Hawkes and Webb, 1962 , p. 187) had proved it well suited to the purpose. The area is situated in the province of Oulu, in the parish of Nivala on map sheet 2344 of the standard base map of Finland (Fig. 1). On the western edge of the area there is the wellknown mined-out nickel ore of Makola. The bedrock in which the Makola sulphide-rich peri-

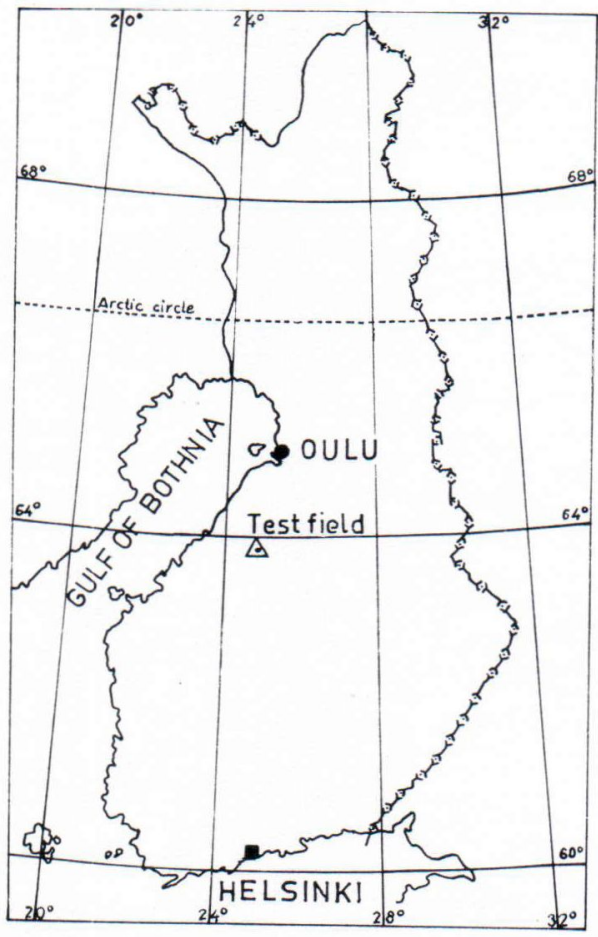

Fig. 1. The location of the Makola investigation area.

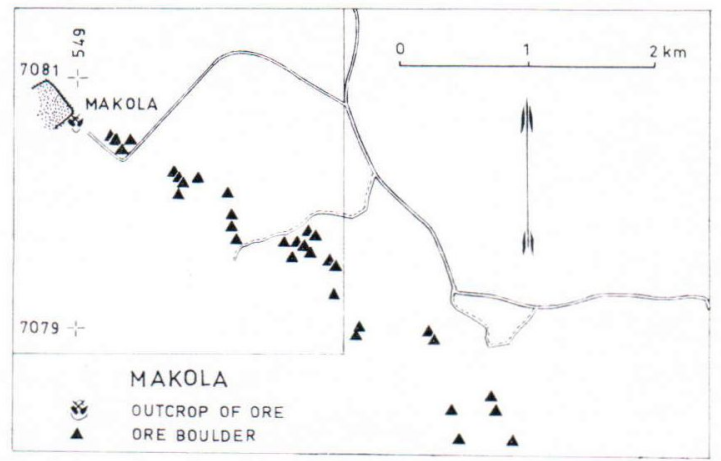

Fig. 2. The outcrop of the Makola nickel ore with the boulder train originating from it. According to Saksela (1949).

dotite is located is mostly mica gneiss. The contact of the ultra-basic massif with the mica gneiss is sharp and fairly regular. The most important ore minerals are pyrrhotite, pentlandite and chalcopyrite (Huhta, 1954).

The drift covering in the Makola area is mainly ground moraine which is $2 \mathrm{~m}$. thick at the most and contains scattered thin layers of sorted material. A thin layer of bogland partially covers the moraine. In connection with prospecting, abundant ore and peridotite boulders have been found in the moraine (Saksela, 1949). They from a long and narrow boulder train in the direction of transport of the glacier (Fig. 2).

\section{Sampling}

The participants in the sampling were the Geological Survey, the Malminetsijä Co and the Exploration Dept. of the Outokumpu Company. The aim of the sampling of the latter was to map in the most systematic way possible the upper part of the moraine. For this purpose samples were taken from the $\mathrm{B}$ horizon of the moraine from a depth of $0.2-0.5$ metres and from the upper of the $C$ horizon from a depth of $0.8-1.4$ metres. The bearing of the profiles in the sampling grid was north south, the spacing between the points 50 metres and the profile spacing 
originally 500 metres. Wherever anomalies occurred, the profile spacing was reduced to 250 metres and later to 125 metres.

The Geological Survey was aiming at the elucidation of the variations of the metal content in the moraine, in particular as a function of depth. Thus, one sample was taken from the $\mathrm{B}$ horizon and samples $\mathrm{C}_{1}, \mathrm{C}_{2}$ and $\mathrm{C}_{3}$ from the $\mathrm{C}$ horizon at distances of $0.5 \mathrm{~m}$. The sampling profiles were arranged perpendicular to the presumed direction of transport of the glacier. The point spacing was 20 metres and the profile spacing 250 metres.

The emphasis in the sampling of the Malminetsijä Co, which had been carried out previously, was placed on the study of the variations of the metal content in the different screen fractions of the till. The sampling profiles were set up in a similar way to that used by the Geological Survey. The point spacing was $20 \mathrm{~m}$ and the profile spacing either $200 \mathrm{~m}$. or $100 \mathrm{~m}$.

\section{The analysis of the samples}

The Geological Survey and the Exploration Dept. of the Outokumpu Co. prepared their samples in much the same way. Samples weighing about $1 / 4 \mathrm{~kg}$ were dried and screened. The Exploration Dept. of the Outokumpu Co, screened fractions $0.83-0.07 \mathrm{~mm}$. and $<0.07$ $\mathrm{mm}$. while the Geological Survey screened fractions $0.83-0.05 \mathrm{~mm}$. and $<0.05 \mathrm{~mm}$. Finer fractions were employed for the analyses. The samples of the Malminetsijä Co. were screened to six grain size fractions $>0.83 \mathrm{~mm}, 0.83-$ $0.42 \mathrm{~mm}, 0.42-0.17 \mathrm{~mm}, 0.17-0.11 \mathrm{~mm}, 0.11-$ $0.07 \mathrm{~mm}$. and $0.07 \mathrm{~mm}$. All the screen separates were analysed.

For the analyses, $3 \mathrm{~g}$ of the sample were weighed into a test tube. $5 \mathrm{ml}$ of concentrated nitric acid were added and the tubes were allowed to boil on a sand bath for 30 minutes. After this, distilled water was added to the tube to bring the total volume up to $30 \mathrm{ml}$. The mixture was swirled, allowed to settle and centrifugued. The analysis was done straight from the centrifugue tube by the atomic absorption method. The samples were analysed for cobalt, copper, nickel and zinc.

\section{The mathematical and automated treatment of the analytical data}

\section{Statistical approach}

The study was started with the elucidation of the statistical features of the observations. The points to be investigated were:

- the results of the analytical data

- the regularity of the function of the content

- the distributions of the content and

- the characteristics of the anomalies.

In connection with this investigation a satisfactory answer was only received to the first two points. The analytical accuracy was established by double analyses. The mean error in the routine of the treatment of the sample and in that of the analysis is about $\pm 5 \%$.

In order to investigate the regularity of the function of the content, special measurements were made by investigating three areas measuring $10 \times 10$ metres. One was located at the anomaly, the second in the so-called slope area and the third in the background area. Thirty three samples per horizon were taken from each area. Of these, 25 were taken from the centre of the area from $20 \mathrm{~cm}$. squares and the remaining 8 from the edges of the area at distances of 5 metres from each other. Conclusions as to the function of the content were drawn with the aid of the means and coefficients of the variations.

In short, the results of the investigation are:

- In both of the areal scales $(1 \times 1 \mathrm{~m}$, and $10 \times$ $10 \mathrm{~m}$.) the variations in the content are of the order of magnitude of tens of percent. They are thus one decade larger than the dispersion due to the analytical methods. This implies that the analytical error can be neglected. 
- Different metals behave in different ways. The copper of the $\mathrm{B}$ horizon has the largest dispersions and the zinc of the $\mathrm{C}$ horizon the smallest. However, the number of observations was too low to enable a reliable determination of behaviour.

- With the exeption of copper, the difference between the size of the areas is not of much significance. Thus, the function of the content (in small scale) has a large random component.

- The coefficients of variation in the background, slope and summit areas do not differ significantly each other.

This part of the investigation indicates that content cannot be considered as a regular mathematical function. The function is better represented by a multiplicative model with a regular and random component.

(1)

$$
\begin{aligned}
\mathrm{f}(\mathrm{x}, \mathrm{y})= & \mathrm{g}(\mathrm{x}, \mathrm{y}) \cdot \mathrm{e}(\mathrm{x}, \mathrm{y}) \cdot \mathrm{e}_{\mathrm{a}} \text {, where } \\
\mathrm{g}(\mathrm{x}, \mathrm{y})= & \text { regular component } \\
\mathrm{e}(\mathrm{x}, \mathrm{y})= & \text { random function and } \\
\mathrm{e}_{\mathrm{a}}= & \text { factor of error depending on the } \\
& \text { number of analyses. }
\end{aligned}
$$

The model has been written for one metal and for one horizon. The model must fulfill the requirements

(2) $\mathrm{E}\{\mathrm{e}(\mathrm{x}, \mathrm{y})\}=\mathrm{i}$ and $\mathrm{E}\left\{\mathrm{e}_{\mathrm{a}}\right\}=1$.

From these it follows immediately that

(3) $\mathrm{E}\{\mathrm{g}(\mathrm{x}, \mathrm{y})\}=\mathrm{E}\{\mathrm{f}(\mathrm{x}, \mathrm{y})\}$.

On the basis of the investigation it can be concluded that the variance of the random part $e(x, y)$ of the coefficient model is not dependent on place nor therefore on the absolute value of $\mathrm{g}$. Further, the order of magnitude of the variances for the random part and the analytical errors are known to be

(4) $\operatorname{Var}\left\{\mathrm{e}_{\mathrm{a}}\right\}=0.05^{2}$ and $\operatorname{Var}\{\mathrm{e}(\mathrm{x}, \mathrm{y})\}=$ $0.3^{2},, 0.6^{2}$.

It can be concluded from the isopleths of the contents (cf. Vuorimiesyhdistys 1967), that the autocorrelation of the random function in relation to distance measured in a horizontal direction behaves in the manner illustrated in Fig. 3.

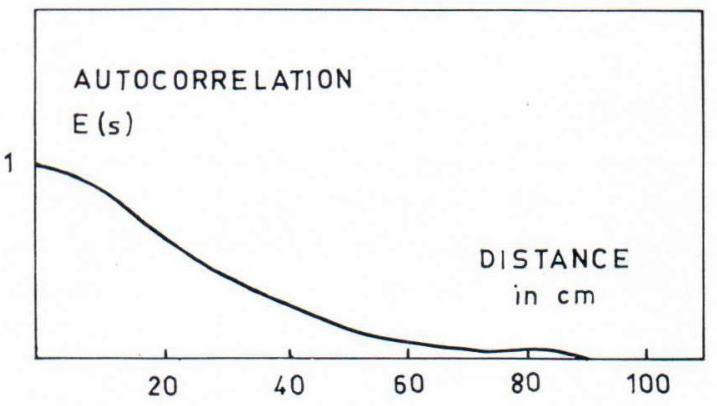

Fig. 3. Schematic representation of autocorrelation.

\section{Smoothing procedure}

According to the foregoing, a considerable random component is always present in the measuring data. This means that there is no great significance in the exact value of the result. The optimal case is that in which the random parts can be completely filtered from the observation values $f(x, y)$. In that case, soleley the regular function $\mathrm{g}(\mathrm{x}, \mathrm{y})$ states the result. In theory, this result is not attained until all the till has been analysed. Consequently, in practice the quality of the results can only be controlled by the sample spacing ( $c f$. Savinskii 1965, Wennervirta 1968).

By smoothing is meant the procedure appled to the observation values which reduces the dispersion of the product $\mathrm{e}(\mathrm{x}, \mathrm{y}) \cdot \mathrm{e}_{\mathrm{a}}$ in such a way that its mean is retained while the mean and variance of the function $\mathrm{g}(\mathrm{x}, \mathrm{y})$ are also retained. In practice, this is accomplished by reducing the disparities between the neighbouring observations while leaving the areal variations unsmoothed.

The smoothing method employed is that of the moving weighted average. The ebservation value is replaced by the weighted average of the observations of the point and its immediate vicinity. Various ways of calculating and weight- 
ing were investigated in this study. They can be divided into two main groups, ie. unidirectional and bidirectional smoothing.

Unidirectional smoothing is called profile smoothing because the smoothing affects the samples taken in profiles. The spacing between the points on the line is $10-15 \%$ of the spacing between the profiles, which justifies the smoothing of the observations on profile alone.

The most simple form for profile smoothing obtained when the spacing of the points on the profile is constant or is considered to be constant. There are always gaps in the profiles so that the method must be such that the gaps do not cause errors. The quantities required in the profile smoothing routine are:

(5) $x_{i}=$ ith observation on the line

$\overline{\mathrm{X}}_{\mathrm{i}}=$ the smoothed value corresponding to the former

$\mathrm{d}_{\mathrm{i}}=$ delta quantity, the value of which is 1 if an observation has been made from point $i$ and 0 if an observation has not been made $\left(x_{i}=0\right)$.

$\mathrm{k}=$ the area of influence of the smoothing which may obtain eg. values 1,2 or 3 .

$a_{j}=$ weighting coefficient, $a_{0}>a_{j}$ and $a_{j}=$ a-j.

With the aid of the former, the profile smoothing routine is defined

(6) $\bar{x}_{i}=d_{i} \sum_{j=-k}^{+k} x_{i+j} \cdot a_{j} / \sum_{j=k}^{+k} d_{i+j} \cdot a_{j}$

The weight coefficients in a five point smoothing, for example, were:

(7) $\mathrm{a}_{-2}=1, \quad \mathrm{a}_{-1}=2, \quad \mathrm{a}_{0}=4, \mathrm{a}_{1}=2$ and $a_{2}=1$.

Fig. 4 depicts the observations on a profile going over an anomaly and the profiles ontained from these observations by the two smoothing methods.

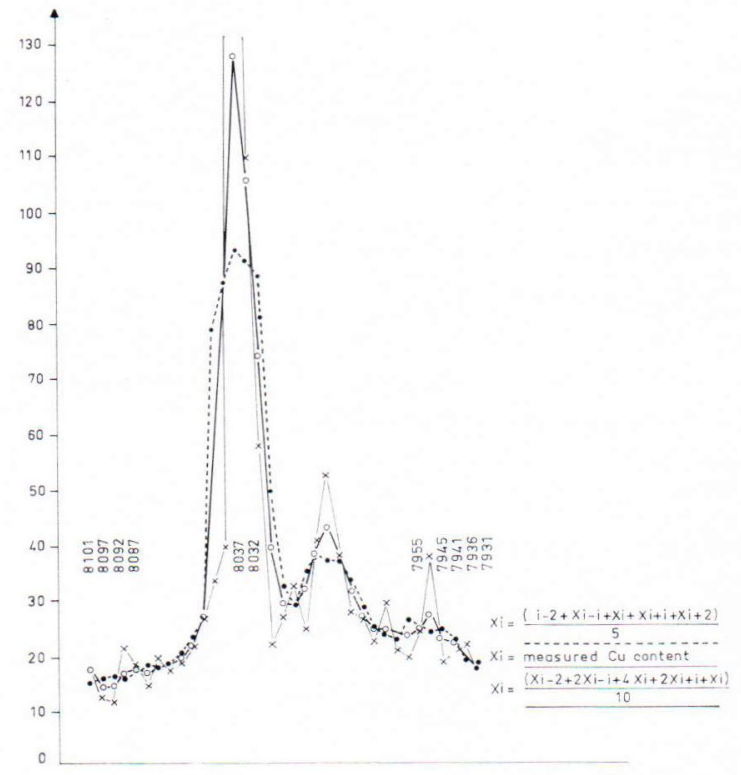

Fig. 4. A profile to which various smoothing was applied.

\section{Improved smoothing procedure}

The moving weighted average does not take the multiplicative nature of the content function into consideration. A better result is obtained with a logarithmic version. However, a smoothing method was developed in the study which does not employ a logarithmic version since the latter has a strong inclination to spread anomalies.

In addition to the dispersion reducing property required of profile smoothing, the following conditions are also essential:

- The smoothing is strongest in the background area

- The smoothing must not spread the anomaly pattern

The smoothing must not press the anomaly peaks too far down.

All these conditions are fulfilled rather well if the smoothing procedure of formula (6) is modified in the following way: 
- Weighting coefficient $a_{j}$ is calculated on the basis of the distance $\mathrm{s}$ ([s]= one meter) between points $i$ and $i+j$ in such a way that $a_{j}=10 / s$. If the distance is less than 30 metres the weighting coefficient receives the value of $1 / 3$. ( $a_{0}$ has the standard value of 0.4 ).

- Point $\mathrm{i}+\mathrm{j}$ is omitted if $\mathrm{s}>210$ metres.

- The weighting coefficients are correted on the basis of the original observations as follows

(8) $a_{0}{ }^{\prime}=a_{0} \cdot\left(x_{i}+x_{m}\right) / x_{m}$

(9) $a_{j}{ }^{\prime}=a_{j} \cdot x_{m} /\left(x_{m}+x_{i+j}\right)$, where $j \neq O$

The first two items on the list are there for program technical reasons and also to ensure that the method is capable of treating various point spacings. The last item is the actual improvement of the method. To the latter was added the condition that, should the content drop more than $30 \%$, then smoothing does not take place.

\section{Computer programs}

Most of the calculations required for the study were done by computer (Elliott 503 in the Finland State Computer Center). In connection with this an automated system of treatment for geochemical data came into being. Before the construction of the system the following characteristics were required of it:

- The system must replace as large a proportion. as possible of the routine jobs done by hand while doing them more cheaply, more speedily and with fewer errors.

- The system must standardise the presentation of the results of the area under investigation.

- The system must aid the geologist in decisions related to the area under investigation by condensing the information obtained into clear units.

The system consists of three fairly large Algol programs (cf. Vuorimiesyhdistys, 1967). If necessary, the programs can be converted so that they are suitable for a more modern computer while at the same time being united into one unit. The characteristics of the system are as follows:

- The system is capable of treating all the areal results occuring in practice at one run. The greatest number of samples allowed is 4000 .

- The system requires that the measuring data be punched according to a standard either on punched cards or punched tape. The punching can be done automatically with the aid of the components attached to the analytical equipment.

- The system requires a rectangular coordinate system which has 10 metres as the unit of lenght. Any profile direction is acceptable.

- The observations can be from either one or two horizons.

- The system outputs the data for the report in reading order.

- The material is arranged in profiles with the output as profile smoothed in this order.

- The distribution data in horizons for each metal are arranged in the form of a histogram. At the same time, the table of the cumulative distribution, the mean and the median are printed.

- The system produces maps on almost perfect scale by using a line printer in such a way that the lines are vertical. A map with the right scale is obtained if the ratio of profile spacing to point spacing is some multiple of $2: 5$. Two copies of each map are printed, a normal map and an anomaly map.

- Finally, the system computes the correlations between the observations and prints them out as well as the linear regression models obtained as a by-product.

In addition to the functions listed above, accurate (Calcomp digital plotter) maps can be drawn by the system so that the output is com posed of the numbers of the measurement points, the analytical data, the smoothed data or the anomalous values. The latter are obtained in 
such a way that all four metals from one horizon are plotted on one map (e.g. Fig. 6).

\section{Factors affecting the results}

\section{The influence of the sample depth}

As has previously been mentioned, the aim of the Geological Survey was to elucidate the variations in the metal contents as a function of sample depth in the moraine. Thus, from each point a sample was taken from the $\mathrm{B}$ horizon and three samples $C_{1}, C_{2}$ and $C_{3}$ from the $C$ horizon at a distance of $0.5 \mathrm{~m}$ from each other. A screen fraction of $0.05 \mathrm{~mm}$ was employed and the analysis was carried out as has already been described.

Three sampling profiles were selected for this paper (Fig. 5). Profile 5.1. is from the top of the ore outcrop, profile 5.2 is $500 \mathrm{~m}$ and profile 5.3. is $1000 \mathrm{~m}$ on the distal side of the outcrop. $C_{1}$, $\mathrm{C}_{2}$ and $\mathrm{C}_{3}(0.5,1.0$, and $1.5 \mathrm{~m})$ were taken as samples and analysed for $\mathrm{Ni}$. The $\mathrm{Ni}$ values were not smoothed. The samples taken from the B horizon are not discussed here because the sampling grid is not complete and it is possible that the contamination resulting from mining operations would distort the picture.

An examination of the figure shows clearly that profile 5.1. the $\mathrm{Ni}$ content of sample $\mathrm{C}_{3}$ is considerably higher than that in $\mathrm{C}_{1}$ or $\mathrm{C}_{2}$. In profile 5.2. in the actual anomaly the nickel contents of $C_{2}$ and $C_{3}$ are almost equal, whereas the value for $C_{1}$ is smaller. The separate peak visible on the profile is not associated with the actual anomaly, but is possibly due to contamination brought about by mining. In profile 5.3. it can be observed that the anomaly smooths out and the share of surface samples $C_{1}$ and $C_{2}$ increases in relation to $\mathrm{C}_{3}$.

On the basis of this examination it can be stated that the nearer one is to the ore outcrop, the better is the picture of the anomaly given by the sample taken from deeper down. On the other hand, the further one is from the cause of
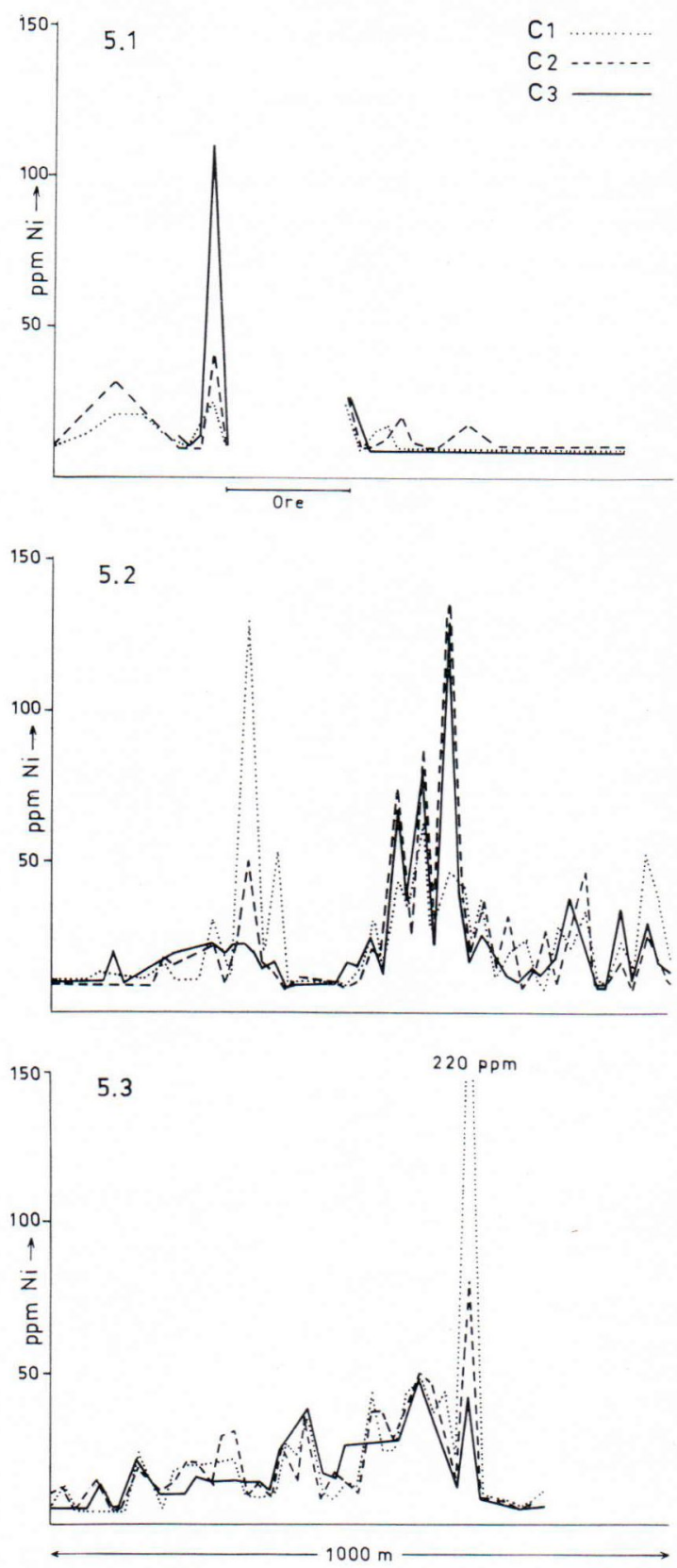

Fig. 5. Moraine profiles. (1) On the top of the ore outcrop, (2) $500 \mathrm{~m}$ and (3) $1000 \mathrm{~m}$ from the ore outcrop. $\mathrm{C}_{1}$, sample depth ca. $0.5 ; \mathrm{C}_{2}$, ca $1.0 \mathrm{~m}$ and $\mathrm{C}_{3}$, ca $1.5 \mathrm{~m}$.

the anomaly the weaker is the anomaly, and samples taken from different horizons give almost the same picture. 


\section{The influence of the screen fraction}

The aim of the Malminetsijä Co. was to elucidate the variations in content in the different screen fractions. The study proved that there is a large dispersion among the different separates, but that the variation in content clearly depends on the grain size of the fractions. For this paper, 20 points were selected from each of two profiles. Two screen fractions, +36 mesh and -197 mesh, were compared in each of the points.

Table 1 clearly demonstrates that in the anomaly area the results given by the fine fraction are considerably larger than that of the coarse fraction. Similarly, the dispersion is much smaller in the fine fraction. On the other hand, in the background area, the values are rounghly the same.

\section{TABLE 1.}

The variations in Ni content in screen fractions +36 mesh and -197 mesh. Makola, Nivala.

\begin{tabular}{|c|c|c|c|}
\hline \multicolumn{2}{|c|}{$\begin{array}{l}\text { sampling profile } 500 \mathrm{~m} \text { from } \\
\text { outcrop }\end{array}$} & \multicolumn{2}{|c|}{$\begin{array}{l}\text { sampling profile } 800 \mathrm{~m} \text { from } \\
\text { outcrop }\end{array}$} \\
\hline $\begin{array}{c}+36 \text { mesh } \\
\text { ppm }\end{array}$ & $\begin{array}{c}-197 \text { mesh } \\
\text { ppm }\end{array}$ & $\begin{array}{c}+36 \text { mesh } \\
\text { ppm }\end{array}$ & $\begin{array}{c}-197 \text { mesh } \\
\text { ppm }\end{array}$ \\
\hline 10 & 15 & 5 & 10 \\
\hline 25 & 25 & 15 & 10 \\
\hline 10 & 10 & 5 & 5 \\
\hline 15 & 10 & 5 & 5 \\
\hline 30 & 120 & 5 & 10 \\
\hline 15 & 25 & 5 & 15 \\
\hline 20 & 30 & 5 & 10 \\
\hline 20 & 50 & 30 & 45 \\
\hline 55 & 150 & 40 & 25 \\
\hline 25 & 350 & 30 & 50 \\
\hline 85 & 200 & 15 & 35 \\
\hline 105 & 200 & 10 & 10 \\
\hline 80 & 135 & 300 & 800 \\
\hline 25 & 95 & 50 & 140 \\
\hline 25 & 30 & 25 & 75 \\
\hline 20 & 50 & 55 & 500 \\
\hline 20 & 15 & 25 & 120 \\
\hline 30 & 120 & 20 & 30 \\
\hline 25 & 120 & 20 & 25 \\
\hline 5 & 135 & 20 & 30 \\
\hline
\end{tabular}

\section{Results}

\section{Map models}

In the map-like output models presented in the following, the geochemical observational data are treated by applying the smoothing principle described on p. 00. In the output of the models both a computer-controlled plotter as well as a line-printed were tried. The geochemical anomalies illustrated in the models were obtained by applying the method employed by Wennervirta (1968).

The output models drawn up by plotter were prepared in such a way that the anomaly values of the different metals, for which were selected $10 \%$ of the highest contents of the material, were collected point by point onto the same map. This map is known as a multimetal map. The result maps (Figs. 6 and 7) depict the anomaly contents of cobalt, copper, nickel and zinc in the $\mathrm{B}$ and $\mathrm{C}$ horizons of the ground moraine. It is natural that the scale of the models drawn up by plotter is accurate in all directions.

The scale of the models done by a line-printer is accurate in different directions only in certain cases ( $c f$. p. 00). This is not the case in Figs. 8 and 9. The figures present the variations in the smoothed concentrations of copper and nickel in the $\mathrm{C}$ horizon of the moraine. The figures were prepared in such a way that $20 \%$ of the highest concentrations are depicted with digits corresponding to the concentration.

\section{Interpretation of results}

The pedogeochemical anomaly of Makola as it appears in Figs. 6-9 does not greatly differ from former representations of it (Kauranne 1959, and Hawkes and Wedd 1962, p. 187). But due to the fact that the number of samples was enlarged and that an increased number of samples was analysed, more details have come to the fore. In its present form the anomaly can be considered as a model example of a syngenetic, glaciogeneous anomaly formed as a result of the mechanical erosion and transport of the glacier. This is evident from the shape of the anomaly, which is long and narrow in the direction of transport of the glacier. The anomaly can still be seen in the $\mathrm{C}$ horizon of the moraine about 


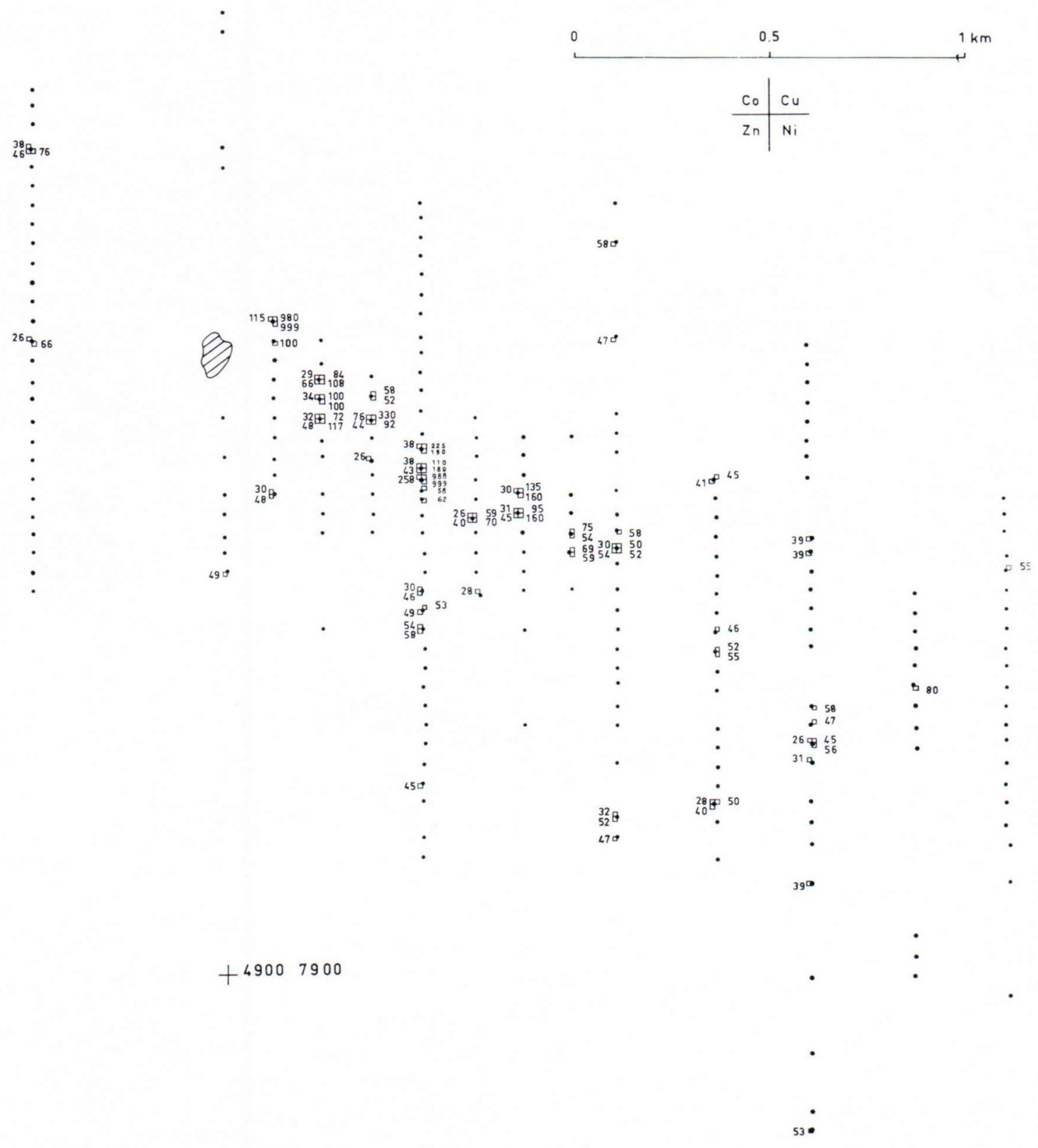

Fig. 6. The anomalous values of cobalt, copper, nickel and zinc in the $\mathrm{C}$ horizon of the moraine. $10 \%$ of the observational data depicted. A manual drawing from the output by plotter. Makola, Nivala.

$2 \mathrm{kms}$. from the outcrop of the ore. The Makola anomaly is unusually long when compared with the other glaciogeneous anomalies known in Finland. The ratio of width to length of the anomaly is about $1: 10$, which is exceptionally low.

The anomaly is characterised by the correlation between cobalt, copper and nickel as can be seen 
TABle 2.

The linear coefficients of correlation between different metals in the B and C horizons of the moraine. Makola, Nivala.

\begin{tabular}{|c|c|c|c|}
\hline & & B horizon & C horizon \\
\hline $\mathrm{Co} / \mathrm{Cu}$ & $\ldots \ldots \ldots$ & 0.38 & 0.89 \\
\hline $\mathrm{Co} / \mathrm{Ni}$ & $\ldots \ldots \ldots$ & 0.48 & 0.85 \\
\hline $\mathrm{Co} / \mathrm{Zn}$ & $\ldots \ldots \ldots$ & 0.55 & 0.40 \\
\hline $\mathrm{Cu} / \mathrm{Ni}$ & $\ldots \ldots \ldots$ & 0.86 & 0.98 \\
\hline $\mathrm{Cu} / \mathrm{Zn}$ & $\ldots \ldots \ldots$ & 0.22 & 0.18 \\
\hline $\mathrm{Ni} / \mathrm{Zn}_{\mathrm{n}}$ & $\ldots \ldots \ldots$ & 0.38 & 0.17 \\
\hline
\end{tabular}

on the multimetal map (Figs. 6 and 7). The same correlations are repeated in the coefficients of correlation presented in Table 2. These correlations are indicative of the nickel ore producing the anomaly.

It can be seen from fig. 6 that the intercorrelation charcteristic of the metals is preserved in the $\mathrm{C}$ horizon of the moraine on the distal side of the anomaly at a distance of over a kilometre from the cause of the anomaly. Further

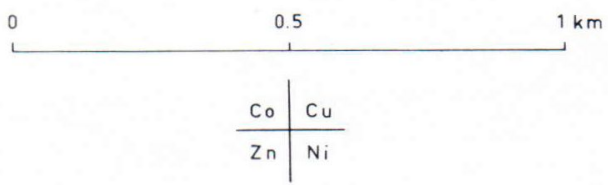

${ }_{55}^{122} \mathrm{O}$

$92 \Phi^{48}$

${ }^{33} \cdot 165$

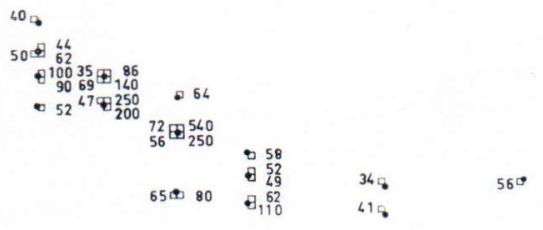

$520^{\circ}$

41.

50 . 
away than this cobalt no longer occurs as an anomaly-forming element in the same way as copper and nickel.

A comparison of the anomalies in the B and $\mathrm{C}$ horizons with each other, shows that they are very similar. However, the coefficients of correlation between the metals (Table 2 ) are not as high in the $\mathrm{B}$ horizon of the moraine as in the $\mathrm{C}$ horizon. This is douptlessly the result of chemical smoothing during the period of formation of the $B$ horizon. If the shapes of the anomalies in the $\mathrm{B}$ and $\mathrm{C}$ horizons of the moraine are compared with each other (Figs. 6 and 7), it can be seen that the anomaly in the B horizon are locating nearer the cause of the anomaly. This can probably be explained as the result of the relative impoverishment in trace metals of the superficial layer of the soil compared with the deeper horizons of the soil. On the other hand, the maximum of anomaly in the $\mathrm{C}$ horizon of the moraine is nearer the cause of the anomaly than is the maximum of anomaly in the B horizon of the moraine.

\section{Summary}

The aims of the study were to elucidate the features relating to a pedogeochemical anomaly and to work out the optimal procedure for the investigating and interpreting of these anomalies. The crucial point in the study was the extention of the automated treatment of data to the statistical analysis of pedogeochemical data and to the presentation od the results. The observations made coincide with the various stages of the pedogeochemical investigation.

1. Results show that it is advantageous to take the samples from the moraine from as deep as is practically possible. This is important when samples are taken from near the ore outcrop. When analysing the fractions of the different coarseness of the moraine, a better contrast of concentration is obtained from the finer fraction than from the coarser fraction.
2. There is a random part in the dispersion of the concentration which is chiefly due to the heterogenity of the moraine. It does not depend on the sampling location nor on the regular part of the function of concentration. The random part of the concentration dispersion can probably only be reduced by taking larger samples. This can be done to greater advantage by collecting a sample from several sub-samples taken near each other. However, it is possible to reduce the random part of the concentration function with a suitable method of smoothing. There are various possible screening methods for random parts, the most advantageous of which is considered profile smoothing. This works according to the moving weighted mean method supplelement with special measures connected with the treatment of anomalies.

3. A plotter is naturally more suitable to the output of pedogeochemical data than a lineprinter, but with some qualifications a line printer is also perfectly feasible. The most important of the qualifications is that a detailed preagreement be reached as to which samplingpoint-symbols be employed. The greatest advantage of the automated treatment of data is obtained when the analytical data are immediately stored, e.g. by a tape puncher, in a form suitable for the subsequent automated data processing.

4. The shape and extent of the glaciogenous anomaly in Makola had already been determined in former investigations. The investigation now carried out does not essentially change the earlier conception. New information concerning the anomaly are the intercorrelations between the concentrations of the metals. The correlations $\mathrm{Co} / \mathrm{Cu}, \mathrm{Co} / \mathrm{Ni}$ and $\mathrm{Cu} / \mathrm{Ni}$ are typical and occur most clearly in the $\mathrm{C}$ horizon of the moraine. The correlations are typical of nickel ore. These intercorrelations can also clearly be seen on the multimetal map. It is remarkable that they extend unchanged in the direction of transport of the glacier for a fairly long distance from the cause of the anomaly. 


:

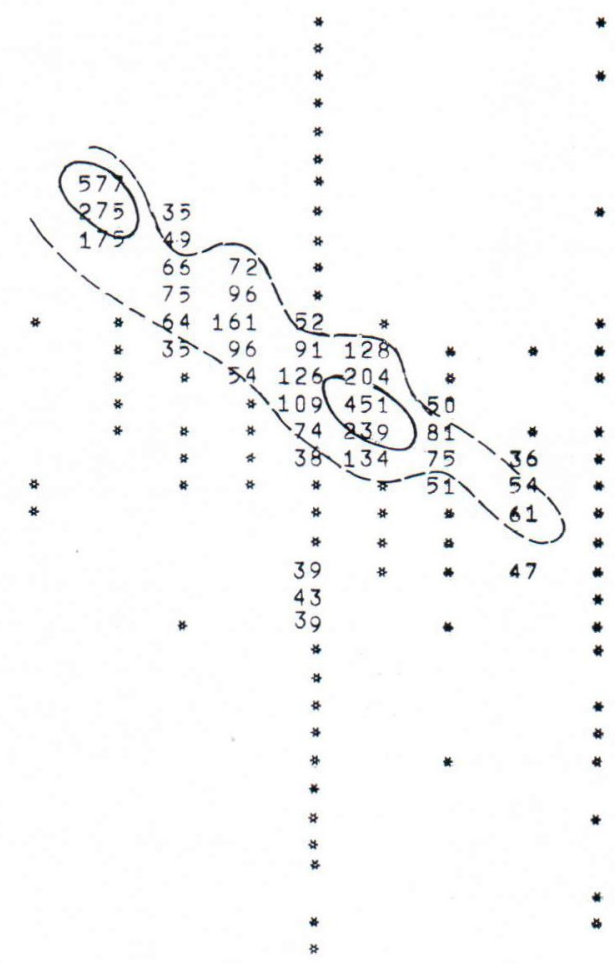

Fig. 8. The anomalous values of copper in the $\mathrm{C}$ horizon of the moraine. $20 \%$ of the smoothed data are presented by numbers. The isopleths which include $10 \%$ and $2 \%$ of the anomalous values were added afterwards by hand. Automated output by line printer. Makola, Nivala. 
$\mathrm{NI} / \mathrm{C}$
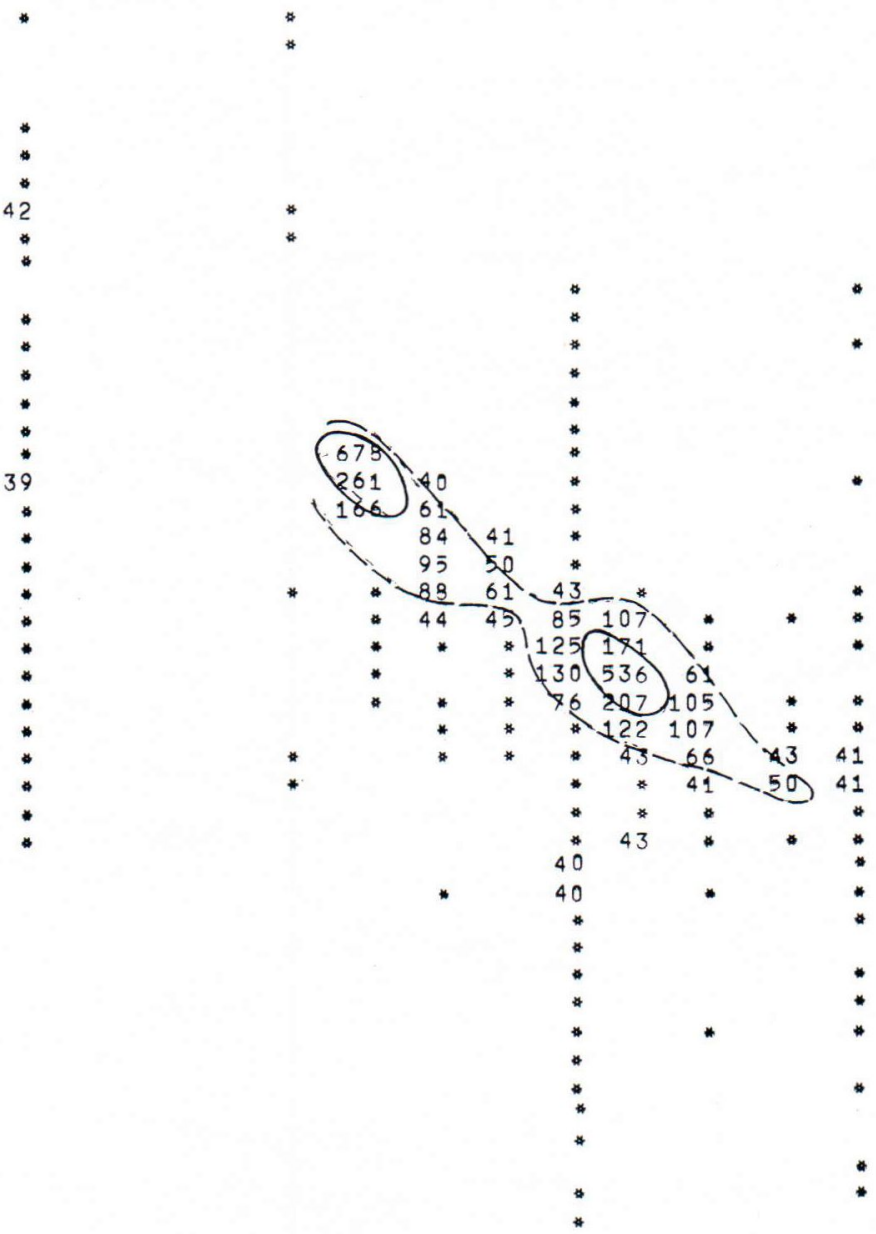

Fig. 9. The anomalous values of nickel in the $\mathrm{C}$ horizon of the moraine. The explanation is the same as in Fig. 10.

Makola, Nivala.

Acknowledgements - Permission to publish this paper was given by the Vuorimiesyhdistys - Bergsmannaföreningen ry. Assistance in the investigation was received from the Geological Survey, the Malminetsijä Co., as well the Exploration Depts. of the Rautaruukki Co. and the Outokumpu Co. The research team received considerable financial support from the Finnish Natural Resources Research Foundation. Mrs. Gillian Häkli translated the paper into English. To all of the abovementioned, the members of the research team are pleased to express their deep thanks. 


\section{REFERENCES}

Hawkes, J. E. and Webb, J. S. (1962) Geochemistry in mineral exploration. Harper and Row, New York.

Huhta, J. (1954) The nickel-copper ore deposit of Makola. Geologinen tutkimuslaitos. Geotekn. Julk. No. 55 , p. 25.

HYVÄRINEN, LAURI (1958) Lyijymalmin prospektoinnista Korsnäsissa. Geologinen tutkimuslaitos. Geotekn. Julk. No. 61, p. 7.

Kauranne, L. K. (1951) Outokummun moreenin mineraalikokoomuksesta. Manucript in the archives of the Inst. Geol. Univ. Helsinki.

- (1958) On prospecting for molybdenum on the basis of its dispersion in glacial till. Bull. Comm. géol. Finlande 180, p. 31.

- (1959) Pedogeochemical prospecting in glaciated terrain. Bull. Comm. géol. Finlande 184, p. 1.
Rankama, Kalervo (1940) On the use of the trace elements in some problems of practical geology. Bull. Comm. géol. Finlande 126, p. 90.

SaKsela, Martti (1949) Malminetsintä, Gummerus Oy, Jyväskylä.

SAvinskiI, I. D. (1965) Probability tables for locating elliptical underground masses with a rectangular grid. Consultants Bureau, Enterprises, Inc., New York.

Tavela, Matti (1957) Moreenin sulfidimineraalien tutkimus malminetsinnässä. Manuscript in the archives of the Inst. Geol. Univ. Helsinki.

Wennervirta, Heik ki (1968) Application of geochemical methods to regional prospecting in Finland. Bull. Comm. géol. Finlande 234.

Vuorimiesyhdistys - Bergmannaföreningen ry. (1967) Geokemiallisten näytteiden käsittely ja tulosten tulkinta. Tutkimusseloste n:o 18.

Manuscript received, December 30, 1969. 